\title{
Uma crítica à interpretação inflacionista do desenvolvimentismo*
}

\author{
Marcelo Curado \\ Marco Cavalieri ${ }^{* * *}$
}

\begin{abstract}
Resumo
Tornou-se comum associar o desenvolvimentismo com irresponsabilidade fiscal e complacência com o processo inflacionário. A difusão da tese do inflacionismo apresentada por Franco (1996, 2005) contribuiu para esta associação. O presente artigo investiga qual a contribuição da literatura econômica entre 1930 e 1964 na formação desta associação. O artigo pretende responder a duas questões: 1. Os expoentes intelectuais do desenvolvimentismo defendiam o uso de mecanismos inflacionários para o financiamento dos investimentos industriais e, portanto, eram inflacionistas no sentido atribuído por Franco $(1996,2005)$ ? 2. Pode-se afirmar que a literatura do desenvolvimentismo defendia certa leniência no controle do processo inflacionário? Para responder estas questões, são analisadas as contribuições dos expoentes intelectuais do desenvolvimentismo no período, especialmente os trabalhos de Roberto Simonsen, Celso Furtado e Roberto Campos. O artigo conclui que não há elementos que sustentem o argumento inflacionista e coloca em discussão a tese da leniência no controle da inflação.
\end{abstract}

Palavras-chave: Desenvolvimentismo; Inflacionismo; Economia brasileira; História do pensamento econômico - Brasil.

\begin{abstract}
A critique of the inflationist interpretation of developmentalism

It has become commonplace to associate Latin American developmentalism with fiscal irresponsibility, and complacency with the inflationary process. The diffusion of the "inflationist thesis" presented by Franco $(1996,2005)$ and others, contributed significantly to this association. This paper investigates how the original developmentalist literature between 1930 and 1964 contributed to the formation of this association. In this regard, the study aims to answer two questions. First, did the exponents of developmentalism defend the use of inflationary mechanisms to finance industrial investment? Second, is it possible to argue that the developmentalist literature defended some leniency with inflation control? To answer these questions, the contributions of intellectual exponents of developmentalism in the period, particularly the works of Simonsen, Furtado, and Campos, are analyzed. The study concludes that there is no support in the original developmentalist literature for Franco's and others' 'inflationist thesis".
\end{abstract}

Keywords: Developmentalism; Inflationism; Brazilian economy; Brazil - History of economic thought.

JEL B29, E31, N96.

* Trabalho recebido em 14 de dezembro de 2013 e aprovado em 8 de setembro de 2014.

** Professor do Programa de Pós-Graduação em Desenvolvimento Econômico da Universidade Federal do

Paraná (UFPR) / Bolsista Produtividade do Conselho Nacional de Desenvolvimento Científico e Tecnológico (CNPq), Curitiba, PR, Brasil. E-mail: mlcurado@gmail.com.

*** Professor adjunto do Programa de Pós-Graduação em Desenvolvimento Econômico da UFPR, Curitiba,

PR, Brasil. E-mail: cavaga@uol.com.br. 


\section{Introdução}

Tornou-se comum associar o desenvolvimentismo à irresponsabilidade fiscal e à complacência com o processo inflacionário. As elevadas taxas de inflação vigentes entre as décadas de 1930 e 1960 - período no qual a ideologia desenvolvimentista exerceu papel predominante na agenda nacional - certamente contribuíram para a formação desta visão. O uso pouco preciso do termo pela mídia, especialmente em contraposição ao monetarismo, igualmente ajudou na difusão de uma visão superficial, quando não equivocada sobre o significado do desenvolvimentismo.

No campo acadêmico, a difusão da visão inflacionista sobre o desenvolvimentismo é outro fator que explica esta associação. Na atualidade, Gustavo Franco é o principal difusor desta visão ${ }^{1}$. Em sua concepção, o velho modelo nacional desenvolvimentista ou de "substituição de importações" era formado por dois eixos centrais: o inflacionismo e a autossuficiência. Este último diz respeito à utilização de proteção à indústria, assim como a uma tendência de redução da participação de concorrentes estrangeiros no mercado nacional, ou seja, diz respeito ao uso do protecionismo como elemento do modelo de desenvolvimento brasileiro.

O inflacionismo é definido como o modelo de financiamento dos investimentos industriais promovido pela expansão da inflação e de déficits fiscais, através do mecanismo de poupança forçada ${ }^{2}$. A origem do inflacionismo, de acordo com Franco (1996, 2005), encontra-se na matriz teórica do desenvolvimentismo que, no tocante à inflação, são as interpretações estruturalistas sobre esse fenômeno elaboradas ao longo das décadas de 50 e 60 na América Latina ${ }^{3}$. Raul Prebisch e Celso Furtado são apresentados como os criadores/difusores do modelo inflacionista; pois seriam os expoentes acadêmicos de um grupo que "nos últimos 60 anos, de variadas maneiras, e com incontáveis vestimentas e disfarces (...) enxergaram funcionalidade na inflação, vale dizer vislumbraram um método nessa loucura" (Franco, 2005, p. 258). Ainda de acordo com a crítica ao

(1) A associação entre desenvolvimentismo e leniência com a inflação encontra-se também presente nos trabalhos do novo desenvolvimentismo. Bresser-Pereira $(2006,2010)$ por exemplo, ao comparar o antigo e o novo desenvolvimentismo afirmam que o primeiro "tem certa complacência com a inflação", conforme assinalam Mollo e Fonseca (2013). Há, no entanto, uma diferença fundamental entre a visão novo-desenvolvimentista e a tese inflacionista. Os primeiros reconhecem que não há na literatura desenvolvimentista do período, especialmente em seus expoentes intelectuais, uma defesa da leniência com os desequilíbrios fiscais e com a inflação, distinção que não é feita por Franco em seus trabalhos sobre o tema.

(2) Em sua definição sobre o inflacionismo, Franco (1996, p. 68) afirma que "a inflação e os déficits fiscais revelaram-se fundamentais como mecanismos para viabilizar, através da poupança forçada, a sustentação de elevados níveis de investimento público, contribuindo significativamente para que as taxas de investimento agregadas permanecessem ao redor de $25 \%$ do PIB".

(3) Para uma discussão sobre as matrizes teóricas do desenvolvimentismo recomenda-se a leitura de Mollo e Fonseca (2013) 
desenvolvimentismo, ao mesmo tempo em que seus autores enxergavam funcionalidade na inflação, especialmente para o financiamento dos investimentos industriais, afastavam-se dos debates sobre os problemas gerados pela inflação, sobretudo das considerações sobre seus efeitos na distribuição da renda. Franco (2005, p. 261) coloca: "É curioso que o desenvolvimentismo brasileiro tenha conseguido preservar em torno de si a aura de projeto nacional redentor e, com isso, tenha logrado distanciar-se de alguns dos principais problemas que criou, como a concentração de renda que, curiosamente, não é vista com uma decorrência da inflação."

Sendo assim, o presente artigo pretende investigar qual a contribuição da literatura econômica desenvolvimentista entre 1930 e 1964 na formação desta associação entre desenvolvimentismo, leniência no controle da inflação e inflacionismo. Pode-se formular o problema tratado nesse texto em duas perguntas. (1) Pode-se afirmar que a literatura desenvolvimentista defendia um tratamento condescendente ou leniente no controle da inflação? e (2) Os expoentes intelectuais do desenvolvimentismo defendiam o uso de mecanismos inflacionários para o financiamento dos investimentos industriais e, portanto, eram inflacionistas no sentido atribuído por Franco (1996, 2005)?

Em alguma medida, o trabalho insere-se no debate recente sobre o significado do desenvolvimentismo, com destaque para a contribuição recente de Mollo e Fonseca (2013), na qual, a partir da análise das duas gestões de Getúlio Vargas, argumenta-se que não existem evidências no campo da história econômica que sustentem a tese da leniência inflacionária. O presente trabalho pretende contribuir para esta discussão, porém com foco distinto, já que analisa a evolução do pensamento econômico brasileiro, especialmente a visão da literatura desenvolvimentista sobre a inflação e sua relação com o processo de desenvolvimento.

Para selecionar os autores do desenvolvimentismo tratados, adotou-se como critério a taxonomia do desenvolvimentismo proposta por Bielschowsky (1988). Nesta perspectiva, o desenvolvimentismo brasileiro entre 1930 e 1964 foi formado por contribuições intelectuais que podem ser organizadas em três correntes principais: (1) o desenvolvimentismo do setor privado, que tinha em Roberto Simonsen seu principal líder intelectual; (2) o desenvolvimentismo do setor público não nacionalista, sob liderança de Roberto Campos e (3) o desenvolvimentismo do setor público nacionalista, cujo principal pensador era Celso Furtado. O artigo se concentra, portanto, na obra desses três autores. Contudo, antes de analisar as ideias desses três expoentes do desenvolvimentismo, é interessante fazer uma breve recuperação do contexto histórico sobre a inflação no período em foco. 


\section{Inflação entre 1930-1964: contexto histórico.}

Esta seção apresenta uma breve reconstituição da evolução histórica da inflação com ênfase no tratamento dado ao tema pelos distintos governos ao longo do período analisado (1930-1964) ${ }^{4}$. Como destacado na introdução do artigo, o objetivo central deste trabalho encontra-se no campo da análise da evolução do pensamento econômico desenvolvimentista sobre a inflação. Não obstante, a contextualização histórica desempenha um papel relevante na compreensão desta discussão na medida em que a evolução das ideias econômicas ocorre em um contexto histórico específico.

A década de 1930 foi marcada por profundas transformações na estrutura política, econômica e social no Brasil. A crise de 1929 evidenciou a fragilidade e a insustentabilidade do modelo agroexportador, reforçando a visão de Vargas sobre a necessidade de, sob o comando do Estado, promover a transformação da estrutura produtiva do país por meio da industrialização, o que concretamente significava superar o modelo agroexportador típico de países atrasados. É neste contexto histórico específico, de colapso do modelo agroexportador, que se deve entender por que o primeiro governo Getúlio Vargas (1930-1945) adotou como objetivo central a elaboração e implantação de um projeto intencional de desenvolvimento para o país, centrado na transformação da estrutura produtiva por meio da industrialização, tal como apontado por Fonseca (2011).

A literatura sobre as transformações estruturais da economia brasileira é vasta. Furtado ([1959], 1968) deixa claro que no início da década de 1930 há um "deslocamento de centro dinâmico", caracterizado pela predominância do setor industrial na geração do produto e renda da economia. Mello (1982) corrobora a análise de Furtado sobre este ponto, mas enfatiza a ainda existente dependência das divisas geradas pelo setor agroexportador. Essa dependência decorria fundamentalmente da necessidade de importações de bens de capital e de insumos necessários nas fases iniciais do processo de substituição de importações.

No que tange ao tema específico da inflação, cabe lembrar que o início da década de 1930 foi marcado pelas pressões deflacionárias típicas dos momentos de significativa retração da demanda agregada. Vale lembrar que estas pressões ocorreram no contexto de abandono do padrão ouro em 1930 e de uma significativa desvalorização do mil reis. Entre 1930 e 1931, a desvalorização de nossa moeda atingiu 55\%, de acordo com Abreu (1999). As pressões deflacionárias permaneceram até 1933, quando foram substituídas por um moderado processo de inflação entre 1933-1939 decorrente, entre outros fatores, da recuperação econômica registrada no período. De fato, como a série histórica do deflator implícito do PIB

(4) Tendo em vista os objetivos do trabalho, o foco principal da análise recai sobre os dois governos de Vargas (1930-1945) e sobre o governo de Juscelino Kubitschek. 
demonstra, entre 1930 e 1945, as maiores pressões inflacionárias foram registradas nos anos finais do primeiro governo Vargas, fenômeno que deve ser explicado, entre outros fatores, pela retração da oferta externa decorrente da Segunda Guerra Mundial e seus efeitos sobre os preços domésticos em um cenário de transformação da estrutura produtiva marcado pelo desenvolvimento das atividades industriais, ainda significativamente dependentes das importações de insumos e bens de capital.

Gráfico 1

Deflator Implícito do PIB (Índice: 1939=100)

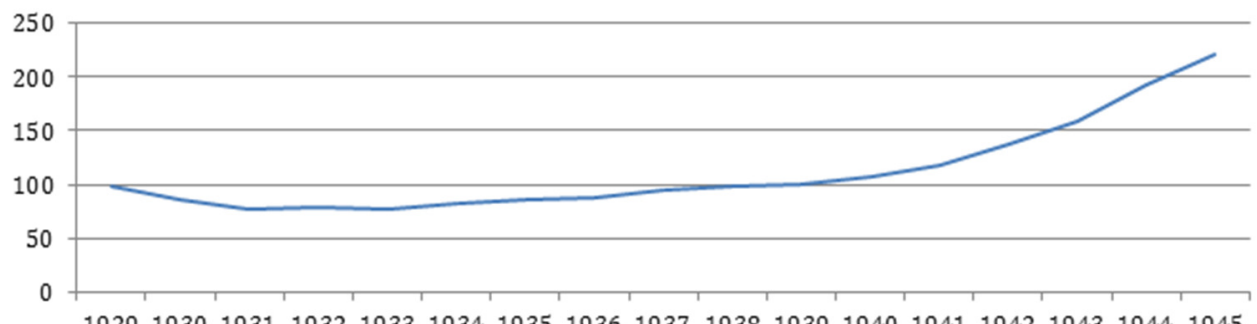

Fonte: Séries Históricas do IBGE. Série Deflatores implícitos, por setor de atividade (1908-1947).

A discussão sobre a política econômica na era Vargas é tema amplamente estudado pela história econômica brasileira. Bastos (2008), por exemplo, sustenta que a política econômica em Vargas deve ser compreendida à luz dos objetivos mais gerais contidos no projeto de desenvolvimento de transformação da estrutura produtiva por meio do processo de industrialização. De toda forma, o ponto essencial, tendo em vista os objetivos do artigo, é destacar que tanto Bastos (2008), quanto Mollo e Fonseca (2013), apresentam evidencias de que a política econômica do primeiro governo Vargas, apesar de seu compromisso com o projeto de desenvolvimento, não pode ser acusada de leniente com a inflação.

Fonseca (2011), ao analisar detalhadamente o segundo governo Vargas, conclui que existia uma clara preocupação do governo com a estabilidade. A manutenção dos valores do salário mínimo é um exemplo deste compromisso. $\mathrm{O}$ autor argumenta que: “mesmo que [o governo] as tenha 'flexibilizado' [as medidas de estabilização] a partir de meados de 1952, nota-se que a preocupação com a estabilização perdurou pelo menos até o final de 1953, com a entrada de Aranha no ministério e a Instrução 70 da SUMOC. Somente a partir de 1954, com a radicalização política, há mudança quanto a esta orientação" (Fonseca, 2011, p. 72).

Em síntese, as pesquisas recentes na área de história econômica apontam que durante os dois governos de Vargas, apesar do compromisso com o projeto desenvolvimentista, não se pode concluir que o governo tenha menosprezado os efeitos danosos da inflação sobre a economia. Bastos (2008), Fonseca (2011) e Mollo e Fonseca (2013) concluem que não existem evidências de "leniência inflacionária" nas duas gestões de Vargas (1930-1945 e 1951-1954). Da mesma forma, não pode- 
se dizer que a gestão Dutra tenha sido leniente ou complacente com a inflação, já que o controle de preços foi eleito como o principal problema econômico a ser enfrentado pela política econômica nesse período.

A gestão de Juscelino Kubitschek (JK) foi marcada pela implantação do Plano de Metas. A magnitude e a concentração dos esforços do governo para cumprir o Plano justificam a sua centralidade nas análises econômicas sobre a gestão JK. É importante lembrar, no entanto, que em 1958 foi lançado o Plano de Estabilização Monetária (PEM), elaborado por Lucas Lopes, com participação de Roberto Campos, então presidente do BNDE. Não restam dúvidas que entre os efeitos concretos do Plano de Metas e a proposta de combate à inflação do PEM, JK deu clara preferência ao primeiro. Roberto Campos, em suas memórias, relata que a opção pelo Plano de Metas e a quase recusa em colocar em prática as medidas antiinflacionárias do PEM foi uma decisão de JK, e não da equipe técnica.

Os níveis elevados de inflação, especialmente no final do governo, e a predominância das medidas de transformação da estrutura produtiva contidas no Plano de Metas, concomitante com a irrelevância concreta do PEM, são elementos importantes para entender por que a gestão de JK, no que tange à questão inflacionária, não recebe da literatura especializada o mesmo tratamento concedido aos governos de Vargas. Objetivamente, entre os denominados governos desenvolvimentistas, apenas $\mathrm{JK}$ pode ser enquadrado como leniente no combate à inflação, o mesmo não se aplicando aos governos Vargas.

Finalmente, para encerrar esta breve seção, caberiam duas discussões. A primeira de cunho empírico, a segunda de natureza teórica. No primeiro plano, cabe ressaltar que comparativamente, a fase mais aguda de aceleração do processo inflacionário ocorreu entre os anos de 1960-1965, apesar dos esforços empreendidos pelo governo no combate à inflação, com destaque para o Plano Trienal elaborado por Celso Furtado. Boianovsky (2011, p. 278) apresenta dados resumidos das médias anuais de variação do custo de vida. Entre 1950-55, período dominado pelo segundo governo Vargas, esta média alcançou $18 \%$ ao ano. Já entre 1955-1960, a média saltou para $28 \%$ ao ano. Finalmente, entre 1960-65, atingiu $62 \%$ ao ano. Vale ressaltar que os picos de inflação não ocorreram, portanto, nos chamados governos desenvolvimentistas. É neste contexto histórico específico que devem ser entendidas as discussões da literatura do período.

Em um segundo plano, da perspectiva teórica, cabe uma observação, por vezes desconsiderada pelas leituras que atribuem a tese inflacionista ao desenvolvimentismo. Os principais expoentes intelectuais do período tinham clareza sobre o impacto, em termos de pressão inflacionária, das mudanças promovidas pelo rápido processo de substituição de importações no período (19301964). Celso Furtado e Roberto Campos, como será discutido na sequência do 
trabalho, tinham clareza sobre as pressões que naturalmente surgiriam das transformações ocorridas na estrutura produtiva. Sugerir que esta consciência implicava em uma defesa da inflação, como pretende a leitura inflacionista, é um grave equívoco, como será demonstrado na seção que se segue.

\section{Literatura desenvolvimentista no "Ciclo Ideológico do Desenvolvimentismo" e a questão inflacionária}

Há uma grande literatura sobre o processo de formação e consolidação do projeto desenvolvimentista no Brasil. Mantega (1984), Bielschowsky (1988) e Fonseca $(2000,2004)$ são algumas referências no tratamento do tema. A abundância e a qualidade dos trabalhos torna desnecessária, e certamente repetitiva, a sua revisão mais detalhada. Todavia, embora as características gerais do desenvolvimentismo sejam amplamente conhecidas, é importante esclarecer que o desenvolvimentismo:

[É] a ideologia de transformação da sociedade brasileira definida pelo projeto econômico que se compõe dos seguintes pontos fundamentais: a) a industrialização integral é a via de superação da pobreza e do subdesenvolvimento; b) não há meios de alcançar a industrialização eficiente e racional no Brasil através das forças espontâneas de mercado; por isso, é necessário que o Estado planeje; c) o planejamento deve definir a expansão desejada dos setores econômicos e os instrumentos de promoção dessa expansão; e d) O Estado deve ordenar também a execução da expansão, captando e orientando recursos financeiros, e promovendo investimentos diretos naqueles setores em que a iniciativa privada seja ineficiente (Bielschowsky, 1988, p. 7).

Cabe adicionar que esse projeto desenvolvimentista não se construiu do dia para a noite; pelo contrário, foi fruto de um processo histórico, tal como descrito em Fonseca (2000, 2004). Foi nessa trajetória de elaboração de uma ideologia econômica que Roberto Simonsen, Celso Furtado e Roberto Campos tornaram-se expoentes de três vertentes diversas do desenvolvimentismo.

Outro aspecto que deve ser sublinhado é que o desenvolvimentismo brasileiro utilizou, em sua construção, uma ampla gama de contribuições teóricas. De acordo com Mollo e Fonseca (2013, p. 228): "O desenvolvimentismo latinoamericano, portanto, é tributário de diferentes correntes teóricas. Sua peculiaridade reside justamente em ter recorrido a diferentes approaches e arcabouços teóricos com vistas a embasar políticas voltadas a superar o subdesenvolvimento, o que lhe confere um caráter que se poderia qualificar, embora com certa licenciosidade, de eclético e pragmático".

Analisados estes pontos mais gerais, passamos para a análise das contribuições específicas de cada autor. 


\section{Roberto Simonsen}

A discussão econômica em Roberto Simonsen indubitavelmente não é tão sofisticada quanto a dos desenvolvimentistas que o sucederam, principalmente se comparada à produção de Furtado. Simonsen era um empresário, um líder da elite paulista e dos industriais da primeira metade do século XX, um profundo conhecedor da história do Brasil e da ciência social e econômica de seu tempo; mas, não era um acadêmico $^{5}$. Ainda assim, é importante lembrar que Bielschowsky (1988) qualifica Simonsen, por seu pioneirismo e originalidade, como "o patrono do desenvolvimentismo brasileiro".

O foco deste artigo é a inflação, mas interessa delinear brevemente e de modo mais amplo a contribuição de Simonsen. A partir dos trabalhos de Bielschowsky (1988), Doellinger (2010) e Teixeira, Maringoni e Gentil (2010) é possível resumir as ideias centrais de Simonsen em três elementos fundamentais. (1) O Brasil deveria promover um processo de industrialização como forma de superação de seu atraso econômico. Esta industrialização deveria ocorrer ainda que as vantagens comparativas ricardianas indicassem um padrão de especialização concentrado na produção de bens intensivos em trabalho não qualificado e recursos naturais. (2) O processo de industrialização também promoveria uma alteração no padrão de especialização comercial do país, reduzindo a importação de bens industriais e, portanto, melhorando a situação de suas contas externas. Além disso, ao ampliar a oferta doméstica de bens industriais, a industrialização ajudaria a reduzir as pressões inflacionárias presentes, especialmente no contexto da II Guerra Mundial. (3) A realização destas transformações na estrutura produtiva e na inserção comercial do país somente poderia ser realizada com participação do Estado e de seu esforço de planejamento. Simonsen, de modo pragmático, já tinha clareza da impossibilidade de o capital privado nacional realizar os investimentos necessários em áreas chave para o processo de industrialização, especialmente na área da infraestrutura econômica e da produção de insumos industriais. Ao mesmo tempo, apoiado nos trabalhos de List e Manoilescu, Simonsen sustentava que, especialmente em suas fases iniciais, o processo de industrialização somente poderia ocorrer com a proteção do mercado interno em relação aos concorrentes estrangeiros.

Estreitando o foco sobre os temas da moeda e da inflação na obra do industrialista, encontramos que suas ideias se coadunam com o sentido geral resumido acima. Dentro do marco do ciclo ideológico do desenvolvimentismo, o primeiro texto em que encontramos referências ao tema do nível de preços e da

(5) Recentemente, alguns autores têm revisto a tese de que Simonsen era apenas um homem prático que apenas flertava com o intelectualismo. Essa literatura sustenta que, se comparado ao seu adversário na célebre "Controvérsia do Planejamento", Gudin, Simonsen demonstra que conhecia razoavelmente bem a literatura social e econômica produzida na Europa e nos Estados Unidos (Curi; Cunha, 2011; Curi; Saes, 2012; Maza, 2002). 
moeda é “As Crises no Brasil” (Simonsen, 1930)․ Escrito como uma análise da situação da economia brasileira após a Depressão de 1929, o texto foi terminado em outubro de 1930, em plena revolução e poucos dias antes de sua prisão ${ }^{7}$. Nesse escrito, entre outros tópicos, Simonsen analisa a situação do crédito, da moeda, dos bancos e da inflação.

$\mathrm{O}$ industrialista afirma que as crises são inerentes ao sistema econômico moderno, sendo inevitável que de tempos em tempos elas aconteçam. Mais especificamente, Simonsen (1930, p. 11) diz que os ciclos de prosperidade e crise duram cerca de 7 a 11 anos. Deste modo, sendo impossível superar a existência de ciclos na economia, o que se pode fazer é tentar mitigá-los, atenuando seus inconvenientes. Nessa tarefa, um bom sistema de crédito, de bancos e "circulatório" é essencial. Ele identifica, entre diversas causas das crises, o "perigo da inflação de crédito" (Simonsen, 1930, p. 10).

Simonsen apresenta uma versão da equação de trocas de Fisher, citando o economista norte-americano. Ele utiliza a equação para mostrar como estaria ocorrendo uma perigosa deflação na economia brasileira devido à contração de numerário levada a efeito pelo governo. Essa contração estaria conjugada com uma diminuição na velocidade de circulação derivada do "fator DESCONFIANÇA (sic)" (Simonsen, 1930, p. 25). Simonsen clama por uma maior elasticidade do meio circulante, pois a deflação seria extremamente prejudicial aos negócios em geral. Todavia, não se pode sustentar que Simonsen estaria a reclamar uma política inflacionista, pois ele deixa bem claro que a estabilidade do valor da moeda é algo de que não se pode abrir mão. Usando um generalista argumento de autoridade, Simonsen (1930, p. 22) escreve: “A unanimidade dos autores modernos e dos peritos financeiros atribui à elasticidade da moeda quase tão grande importância como a sua estabilidade (sic)." Anote-se: a elasticidade do meio circulante é de importância menor do que a estabilidade, pois ele utiliza a expressão "quase tão grande". O industrialista paulista acredita que o ideal é a manutenção de um sistema que combine estabilidade do valor da moeda e elasticidade da mesma.

Em um texto do ano seguinte, "As Finanças e a Indústria”, Simonsen retoma o mesmo assunto quase nos mesmos termos. Nesse escrito, Simonsen (1931, p. 47) afirma que não se tinha, àquele tempo, moeda estabilizada e elástica. Essas duas características são essenciais para criar um “aparelhamento de produção”, isto é, para incentivar a poupança de fundos que deveriam estar disponíveis para o investimento. Simonsen (1931, p. 47) cita Robert Owen, o socialista utópico inglês, que dizia: “como se poderá esperar real justiça economica quando se paga trabalho com moeda

(6) Há uma entrevista de Simonsen sobre a reforma monetária de 1926 anterior à década de 1930.

(7) Preso pelos revolucionários, ele foi solto 15 dias depois.

(8) Ênfase em maiúsculas do original. 
que fluctua de valôr; seria o mesmo que esperar pontualidade num mundo em que a hora variasse continuamente de extensão." A parca poupança brasileira, para o industrialista, era resultado de dois fatores, os hábitos, a "índole do nosso povo", e a instabilidade da moeda que enfrentava sucessivas inflações e deflações (Simonsen, 1931, p. 48). Tanto em "As Crises no Brasil" quanto em "As Finanças e as Indústrias", Simonsen apresenta dados sobre custo de vida, câmbio, meio circulante e encaixes do Banco do Brasil. Assim, o industrialista sempre procurava embasamento empírico, algo que lhe foi caro durante toda a sua atuação intelectual.

Em outro escrito de 1944, “A Agricultura e a Indústria”, parte da coletânea "Elos da Indústria", Simonsen (1944) volta a citar o problema da inflação. Nesse texto a inflação é atacada sem tergiversação. As causas da inflação são atribuídas à "falta de transportes" e à "inconsciência dos especuladores". Além disso, ele alerta que se a inflação, naquele momento, atingia mais as classes menos favorecidas, logo seria um problema para todos. A novidade nesse texto é a solução. Diz ele que as entidades industriais já haviam recomendado ao governo a criação de um Conselho Nacional dos Preços (Simonsen, 1944, p. 9-10). O pedido de Simonsen, como representante da classe industrial, para que o governo atuasse mais decididamente, inclusive criando um órgão para lidar com o controle de preços, se coaduna com sua ideia geral sobre a necessidade de planejamento econômico, tema de seus famosos textos da controvérsia com Gudin.

O início do debate com Gudin se deu com a publicação de um relatório de Simonsen, que era presidente do Conselho Nacional de Política Industrial e Comercial. O relatório, originalmente apresentado ao Conselho em 16 de agosto de 1944, defendia a promoção de um processo de industrialização como forma de superação do subdesenvolvimento. Para tanto, dado o precário estado de desenvolvimento do país e a fragilidade do capital privado nacional, ele propunha que a industrialização fosse conduzida a partir de um redobrado esforço de planificação da economia brasileira. Novamente, Simonsen assinala a inflação como um problema que atingia principalmente os menos favorecidos. Defendia que o "encarecimento do custo de vida da população" piorava a condição de vida, especialmente dos trabalhadores. Além disso, a inflação, ao reduzir os rendimentos reais dos trabalhadores, limitava as possibilidades de ampliação do consumo e do crescimento econômico do país.

É sempre bom ter em mente - como destacam, entre outros, Carone (1971), Maza (2002, 2004), Teixeira, Maringoni e Gentil (2010) e Curi e Cunha (2011) que Simonsen era um líder industrial interessado em ampliar o papel da indústria no cenário nacional. A expansão da capacidade de produção da indústria nacional contribuiria para diminuir os históricos desequilíbrios entre o comportamento da oferta e da demanda. Agora, então, aparece uma tese que vai ser incorporada pelo desenvolvimentismo posterior, qual seja, a defesa da ideia de que as restrições de 
oferta derivadas do parco desenvolvimento industrial e a resultante elevada demanda por importações de bens industriais eram as causas fundamentais da inflação brasileira. É importante lembrar que na Primeira Guerra Mundial (1914-1918), na crise de 1929 e durante a Segunda Guerra Mundial (1939-1945), a economia brasileira sofreu severas restrições na oferta de bens industriais importados.

Sendo assim, do ponto de vista teórico, Simonsen apresentava uma construção bastante eclética para justificar o processo de inflação brasileiro. Por um lado, ao afirmar que o processo de industrialização gerava desequilíbrios entre oferta e demanda, o autor antecipava a visão estruturalista da inflação. Por outro lado, defendida também a presença de causas quantitativistas, como fizera nos textos da década de 1930. No relatório da controvérsia, ele afirma: “(...) o considerável aumento do meio circulante agravou a elevação dos preços e estamos a braços com um encarecimento de vida que se acentua continuamente" (Simonsen [1945], 2010, p. 42).

Considerando essa visão da inflação apresentada na controvérsia, é importante ressaltar a oposição que lhe faz a resposta de Gudin, intitulada "Rumos da política econômica". Entre as conclusões do liberal brasileiro destaca-se o item VII, letra b, no qual propõe: “(...) que a política monetária tenha como principal objetivo a manutenção da estabilidade do poder de compra da unidade monetária" (Gudin, [1945], 2010, p. 121). Por sua vez, Simonsen sustenta que a política monetária deve ser subordinada à política econômica geral de fomento das atividades produtivas. Ao comentar a visão de Gudin, Simonsen ([1945], 2010, p. 171) afirma que: “(...) é princípio reconhecido pelas classes produtoras a subordinação da política monetária à política econômica geral de fomento das atividades produtivas, e ampliação do capital nacional".

A despeito dessa subordinação da política de estabilização à política de crescimento, cabe anotar que em Simonsen a inflação é, sem dúvida, um mal. Ademais, inexiste nos textos analisados qualquer menção ao fato de que a inflação poderia auxiliar no processo de industrialização (apesar de Simonsen reconhecer que desinflações são custosas em termos de atividade econômica). Aliás, o que se encontra é o contrário, a industrialização ajudaria na contenção do processo de aumento generalizado de preços. Ademais, nos escritos do começo da década de 1930, a inflação é mostrada como responsável por obstaculizar os negócios, reduzindo inclusive a propensão à poupança do brasileiro (algo que se configura o contrário da tese da poupança forçada). Por fim, é necessário notar que as análises de Simonsen são sempre contextuais. Há a interpretação geral de que a inflação é decisivamente um mal, mas suas causas são sempre consideradas em função do cenário específico do Brasil e das políticas econômicas conduzidas no período. Essa especificidade na interpretação dos fenômenos econômicos deriva de influências que Simonsen teve de autores como Friedrich List, Mihail Manoilescu e dos 
institucionalistas norte-americanos. Essa valorização do específico e a negação da universalidade das teorias econômicas estariam no núcleo metodológico do desenvolvimentismo e do estruturalismo latino-americano.

\section{Celso Furtado}

Da mesma forma que Simonsen, pode-se afirmar que Furtado via na inflação um grave problema econômico a ser enfrentado. Furtado, em boa parte de sua produção intelectual neste período, procura desvendar o processo histórico de constituição do subdesenvolvimento latino-americano. No entanto, sua sólida formação teórica em economia permitiu que sua interpretação dos processos históricos concretos ultrapassasse os limites da descrição factual dos acontecimentos, como observa, entre outros, Cardoso (2013). Uma forma bastante sintética e elegante de apresentar este ponto é apresentada por Maurício Coutinho, no livro organizado por Coelho e Granzieira (2009), ao afirmar que Furtado "fazia esquemas de abstração da história". A discussão sobre a inflação brasileira feita por Furtado é um exemplo deste processo de "esquemas de abstração da história". A interpretação das causas da inflação muda de acordo com as alterações processadas no sistema econômico. Estas causas são distintas, por exemplo, na economia agroexportadora e na economia industrial do pós-guerra. Nas palavras de Boianovsky (2012, p. 283), a interpretação de Furtado sobre as causas da inflação brasileira "evolved in response to changing economic circumstances."

Todavia, antes de abordar a evolução do pensamento de Furtado sobre o tema é necessário estabelecer alguns pontos mais gerais que ajudam na compreensão do que seja a construção de "esquemas de abstração da história". A obra de Celso Furtado é marcada por uma conclusão, central na análise de qualquer tema sobre o autor: o subdesenvolvimento se auto-reproduz, perpetuando-se no tempo. O subdesenvolvimento não é eliminado a partir do funcionamento dos mecanismos de mercado; pelo contrário, seu funcionamento, sob certas condições, tende a ampliálo. A manutenção do subdesenvolvimento e sua reprodução guarda uma estreita relação com a dependência externa, típica de países periféricos exportadores de bens primários (Furtado [1959], 1968). Estes países, tais como o Brasil, estavam fadados a ter graves problemas em suas contas externas dada a tendência à deterioração dos termos de troca. A queda relativa dos preços dos produtos básicos em relação aos bens industriais implicava, para manter o equilíbrio nas contas externas, em aumentar o quantum exportado e reduzir o quantum importado. No entanto, isto era inviável em função da elevada elasticidade-renda da demanda por importados vis-àvis à baixa elasticidade-renda das exportações. O resultado final deste processo é que as fases de expansão do produto na economia agroexportadora eram seguidas por crises externas decorrentes dos recorrentes desequilíbrios no Balanço de Pagamentos. 
Neste contexto, a inflação na obra de Furtado deve ser compreendida como um subproduto da dependência externa. É necessário lembrar que o Brasil importava bens industriais cujos preços relativos tendiam a ser sistematicamente superiores aos dos bens exportados, o que objetivamente reduzia o poder de compra relativo de nossa produção. Além disso, dado o papel do país na divisão internacional do trabalho, a manutenção da renda do setor agroexportador e a sustentabilidade das contas externas implicava em recorrentes políticas de desvalorização da moeda. Estas políticas apresentavam como subproduto o agravamento do encarecimento dos bens importados em moeda local, constituindo-se em fontes recorrentes de pressões inflacionárias.

Finalmente, a estrutura produtiva da economia agroexportadora caracterizava-se por ser heterogênea. O Brasil tinha uma estrutura produtiva dual na qual o setor cafeeiro voltado para o mercado externo exibia elevada produtividade, enquanto o setor produtor de bens agrícolas, voltado para o mercado doméstico, adotava técnicas rudimentares e exibia baixa produtividade. O resultado é que o excesso de oferta de café convivia com restrições na oferta de bens agrícolas para o mercado doméstico. Ao longo do tempo, esta inelasticidade na oferta de bens agrícolas era outra fonte de pressões inflacionárias relevantes.

Em síntese, na economia primária exportadora, a inflação "fora o instrumento de socialização das perdas dos grupos exportadores. Quando baixava o preço internacional do café, depreciava-se a moeda brasileira, elevando-se os preços das importações e reduzindo-se ou anulando-se, em moeda nacional, as perdas dos exportadores" (Furtado, 1985, p. 178). A mudança da estrutura produtiva através do processo de industrialização e a consequente redefinição do papel do Brasil na divisão internacional do trabalho seriam elementos essenciais para a superação da dependência externa e, portanto, promoveriam a eliminação das fontes estruturais de pressões inflacionárias.

A inflação na economia brasileira em industrialização tem outras causas acentuam-se neste momento as interpretações estruturalistas de Furtado. Nas fases iniciais do processo de substituição de importações, o crescimento da renda gerava uma demanda por bens importados - necessários para a realização dos investimentos industriais - superior à expansão na capacidade de importação, ainda fortemente dependente das exportações de café e outros produtos agrícolas de baixa elasticidade-renda da demanda. O crescimento da renda e, portanto, da demanda interna acima da capacidade de importar, o que em última instância definia o ritmo de expansão da oferta, constituía-se na causa fundamental da inflação brasileira. Argumentos desta natureza encontram-se presentes em Furtado ([1949] (1968), 1952, 1958a, 1958b e 1959). A passagem abaixo apresenta este ponto com clareza: 
Como conciliar essa tendência a aumentar as importações, resultante do próprio desenvolvimento, com a impossibilidade de aumentar a capacidade para importar? Na verdade foi essa a situação que conhecemos desde 1930 até muito recentemente... Sempre que as exportações (considerada constante a relação de intercâmbio) não cresçam paralelamente com a procura de importações, o processo de crescimento criará desequilíbrios, que se manifestam em excedentes de produção interna e em saldos desfavoráveis no balanço de pagamento esses desequilíbrios vão sendo corrigidos com atraso e quase sempre em forma dolorosa. E isso contribui para dificultar a política de estabilização e para tornar a inflação inseparável do processo de desenvolvimento. A inflação que acompanha o desenvolvimento econômico em nosso país não é, portanto, fundamentalmente, um problema monetário. A causa última do desequilíbrio está na disparidade entre o crescimento da renda e o da capacidade para importar (Furtado, 1952, p. 3).

Furtado, como argumentam, entre outros, Baer (1967), Kay (1991) e Boianovsky (2012), contribuiu de forma decisiva para a construção da interpretação estruturalista da inflação. De forma bastante objetiva, pode-se afirmar que a visão estruturalista da inflação propunha, em sua essência, que: (1) a inflação na América Latina não era o resultado exclusivo da expansão monetária oriunda de desequilíbrios fiscais e/ou equívocos na condução da política monetária, tal como proposto pela literatura ortodoxa e pelos organismos internacionais, como o FMI; (2) existiam razões estruturais que explicavam o histórico processo de inflação latino-americano, com destaque para os desequilíbrios nas contas externas (derivados da inserção externa da região concentrada na exportação de produtos primários e na importação de bens industriais) e seus efeitos sobre a dinâmica de preços; e, (3) o combate à inflação deveria concentrar-se em suas causas estruturais (o desequilíbrio das contas externas) e não na sua manifestação monetária, o que na prática implicava negar os mecanismos ortodoxos de combate à inflação via contração monetária e/ou políticas fiscais contracionistas. Além das contribuições de Furtado, destacam-se como essenciais na construção da interpretação estruturalista sobre inflação os trabalhos de Noyola (1956), Sunkel (1960) e Seers (1962).

Em sua "Fantasia Organizada", Furtado afirma que na construção da visão estruturalista da inflação "ninguém expressou tão claramente a essência de nosso argumento quanto Noyola, em Conferência na Escola Nacional de Economia da Universidade do México, em começos de 1956" (Furtado, 1956, p. 185). Noyola (1956) separa os fatores geradores de pressões inflacionárias e os mecanismos de propagação da inflação. Os primeiros seriam derivados das rigidezes estruturais típicas de economias subdesenvolvidas, com destaque para as pressões derivadas do processo de substituição de importações em um contexto de restrição de divisas e de inelasticidade da oferta de alimentos para o mercado interno. A pressão inflacionária se manifestava, de acordo com Noyola (1956), através dos mecanismos monetários 
de propagação, isto é, através da expansão da moeda (passiva). Da perspectiva estruturalista de Noyola e Furtado, os monetaristas não eram capazes de perceber as causas estruturais da inflação (a essência do fenômeno), concentrando sua análise sobre aquilo que era secundário. As causas estruturais envolviam, por exemplo, inelasticidades de oferta de diferentes produtos agrícolas e os termos de troca.

A desaceleração do crescimento industrial no fim da década de 50 e a sensível piora dos resultados fiscais ${ }^{9}$ tiveram impacto sobre a concepção das causas da inflação em Furtado. As causas estruturais da inflação perdiam sentido com a desaceleração do crescimento. Ao mesmo tempo, o excesso de gasto público passa a ganhar espaço como elemento causal da inflação. A mudança na interpretação de Furtado sobre a relação entre inflação e déficit público é apresentada por Boianovsky (2012):

Furtado, however, would change his mind about the role of fiscal deficits in Brazilian inflation, as data became available in the late 1950s indicating the increase of government demand. As explained by Furtado $(1964,498)$ at the 1963 Rio Conference, the type of inflation that started in the mid-1950 and continued until the early 1960s differed from the previous one. Its primary cause lies in a deep disequilibrium of the public sector, which was called forth to take up concrete responsibilities in the process of capital formation, without regard to the fact that the fiscal apparatus had not undergone the necessary adaptation (Boianovsky, 2012, p. 310).

A desvalorização da moeda como mecanismo de compensação da redução do preço do café no mercado internacional, as pressões estruturais derivadas do crescimento das atividades industriais e os déficits públicos crescentes passam a aparecer como elementos causadores da inflação brasileira em distintos momentos históricos. Desse modo, em consistência com a ideia de que Furtado era um construtor de "modelos abstratos da história", suas interpretações sobre a inflação mudavam com as alterações na economia real - um elemento de suas ideias destacado por Baer (1967) e Boianovsky (2012).

Da mesma forma que suas interpretações sobre as causas da inflação brasileira no período analisado variaram de acordo com a evolução concreta do sistema econômico, a forma de combate à inflação também oscilou. $\mathrm{O}$ processo de industrialização, ao mesmo tempo em que criava pressões sobre a inflação, contribuiria, após a instalação da indústria pesada, para sua redução. O processo de industrialização era, assim, dialeticamente a causa e a solução para a inflação estrutural dos anos 50. Já no contexto de desaceleração do crescimento do início dos anos 60, ganham espaço as causas fiscais da inflação. É neste contexto histórico que

(9) O resultado primário das contas do governo que se encontrava praticamente equilibrado em 1960 registrou um déficit de 4,21\% do PIB em 1962. 
deve ser entendido o Plano Trienal, elaborado por Furtado no Ministério da Fazenda. O programa de combate à inflação centrado no controle dos gastos públicos e na redução da expansão monetária é o resultado, além do contexto político específico, das mudanças ocorridas nas causas da inflação brasileira. O processo inflacionário é, em Furtado e nos outros desenvolvimentistas e estruturalistas, um fenômeno com causas, momentos e economias distintos - como marca Boianovsky (2012, p. 292).

Finalmente, é importante discutir o tema dos impactos da inflação sobre a distribuição. Ao contrário do que enuncia Franco (1996, 2005), Furtado tinha plena consciência dos efeitos perversos da inflação sobre a distribuição da renda. Isto fica evidente desde seus primeiros trabalhos. Furtado (1950), por exemplo, ao discutir a inflação na economia agroexportadora afirma que a compensação (parcial) da queda dos preços do café através da desvalorização da moeda se constituiu em um mecanismo de "socialização dos prejuízos" do setor agroexportador com toda a sociedade. Isso ocorria porque a manutenção da rentabilidade do setor externo promovia a alta dos preços dos produtos importados no mercado local, pressionando a inflação. Tratava-se, portanto, de um mecanismo "de transferência para a massa dos prejuízos impostos às empresas agroexportadoras pela contração do mercado externo" (Furtado, 1950, p. 4). Fica evidente que para Furtado a inflação era um problema distributivo, no qual as vantagens obtidas por alguns geravam perdas para os demais. Em outros termos, Furtado, ao contrário do que propõe a leitura de Franco, tinha plena consciência que a transferência de renda derivada do processo inflacionário tinha um viés distributivo perverso.

É importante anotar que, já em 1994, Carolyn Craven publicava um artigo na prestigiada revista History of Political Economy buscando desmistificar a relação entre o estruturalismo cepalino e sua suposta recomendação de utilização da inflação como instrumento de promoção de crescimento. A autora, depois de analisar documentos publicados pela Cepal e por autores ligados à instituição especialmente Noyola e Sunkel - afirma: "A general misinterpretation of structuralism as promoting inflationary policies in order to maintain growth exists, although Noyola, Sunkel, and UNECLA ${ }^{10}$ publications were vigorous in prescribing anti-inflationary measures, just as vigorous as they were in denouncing conventional stabilization plans." (Craven, 1994, p. 18) ${ }^{11}$.

O título do artigo de Craven, "A Transformation Problem: monetarism to structuralism in the Commission for Latin America", diz respeito ao fato de que os economistas da CEPAL teriam transitado de interpretações mais ortodoxas da inflação latino-americana para a explicação estruturalista. Todavia, o importante é

(10) Embora seja mais comum o uso da sigla em inglês Ecla para se referir à Cepal, Carolyn Craven prefere Unecla, de United Nations Economic Commission for Latin America.

(11) Os documentos pesquisados por Craven cobrem o período de 1948 ao início da década de 1960. 
que mesmo mudando - abruptamente, segundo Craven (1994, p. 3) - a interpretação sobre as causas da inflação, se mantém o fato de que não há a recomendação para que se utilize a inflação como instrumento promotor do crescimento. A inflação é percebida, portanto, como um mal para as economias latino-americanas.

\section{Roberto Campos}

Finalmente, cabe analisar a posição de Roberto Campos sobre a inflação. O autor foi, de acordo com Bielschowsky (1988), o principal expoente do desenvolvimentismo do setor público não nacionalista. Campos, em seu livro de memórias, "A lanterna na popa", admite que a leitura de Bielschowsky é "objetiva e correta", ainda que a designação desenvolvimentista não nacionalista seja "menos feliz". De acordo com Campos (1994, p. 197): “os desenvolvimentistas não nacionalistas, ou para usar um termo melhor, desenvolvimentistas liberais, tinham muitos pontos em comum com a escola liberal clássica, chefiada por Eugênio Gudin e Octávio Bulhões. Comungavam com estes na preocupação com os problemas de estabilização, na aceitação do investimento privado como motor do desenvolvimento, na oposição ao estatismo e a abertura para capitais estrangeiros." Estas considerações não podem encobrir, e este é o ponto central na classificação proposta por Bielschowsky, que os trabalhos de Roberto Campos nas décadas de 1950 e 1960 apoiavam o processo de industrialização e entendiam que seu desenvolvimento dependia da capacidade de planejamento do Estado brasileiro.

A observação de seus trabalhos no período, especialmente Campos (1953, 1957, 1963, 1994), e de trabalhos específicos sobre o autor, com destaque para o trabalho de Godoy (2007), evidenciam sua preocupação com a inflação. Seu rigor com o tema da inflação pode ser sumarizado por sua frase clássica: "uma pequena inflação é como uma pequena gravidez". A preocupação com os efeitos danosos da inflação para o desenvolvimento foi uma constante na obra intelectual do autor em sua fase desenvolvimentista.

É interessante analisar como se deu ao longo do tempo a evolução de seu pensamento no que tange especificamente ao tema das causas da inflação brasileira. Campos foi paulatinamente migrando de uma construção estruturalista para uma análise mais ortodoxa das causas da inflação. Em seus trabalhos na década de 50, especialmente em Campos (1953), há uma clara ênfase no que denominava "elemento inflacionário estrutural, inerente ao processo de industrialização". A ideia básica é que a inflação era o resultado natural do processo de industrialização e seus efeitos sobre a economia. Campos (1953) apresenta quatro fatores causadores da inflação: (1) o aumento da renda e seu efeito sobre demanda; (2) a urbanização e seus efeitos sobre os hábitos de consumo da população; e, (3) a produção de equipamentos em detrimento da produção de bens de consumo. Desses, três têm relação com a industrialização. Adicionalmente, Campos destacava ainda a 
inelasticidade da oferta da produção agrícola como um "germinador" de pressões inflacionárias.

Assim como em Furtado, as alterações processadas na economia brasileira, especialmente a redução no ritmo de crescimento e nos avanços do processo de industrialização na primeira metade da década de 60 , foram incorporados na visão de Campos sobre as causas do processo inflacionário. $\mathrm{O}$ abandono das teses estruturalistas e a convergência com as interpretações de natureza monetária são evidentes nos trabalhos do autor na década de 60. Bielschowsky (1988, p. 119), ao sintetizar os argumentos de Campos (1967), argumenta que "sua posição básica era que, no caso brasileiro, a inflação vinha sendo causada por excesso de demanda, viabilizada por déficits no orçamento público e por expansão do crédito anormal, provocada por uma insuficiência de oferta que advinha muito mais de má gestão da política econômica do que de rigidez estrutural"

A evolução do pensamento do autor sobre o tema da inflação revela um dos aspectos mais importantes de sua contribuição para a literatura econômica do período: o ecletismo. Bielschowsky (1988, p. 111) afirma que "Campos era, efetivamente, do ponto de vista teórico, o que se pode chamar de um economista eclético". Este ecletismo também estava presente em sua análise sobre a inflação. De acordo com o próprio autor: "Nessa controvérsia entre monetaristas e estruturalistas, respectivamente simbolizados por FMI e pela Cepal, eu me posiciono em igual distância dos dois polos, pois meu ponto de vista é bastante eclético" (Campos, 1963, p. 157).

Em síntese, a preocupação com as causas e os impactos da inflação sobre o sistema econômico era tema presente nos expoentes da literatura desenvolvimentista do período. Não há, no entanto, homogeneidade nas interpretações desenvolvimentistas sobre as causas do processo inflacionário brasileiro. Um traço comum nesta literatura é associar, em determinados momentos de sua produção intelectual, a inflação ao processo de industrialização. Ao mesmo tempo, os avanços na industrialização permitiriam, de acordo com Simonsen [1945], (2010), Campos (1953) e Furtado ([1949] (1968), 1952, 1958a, 1958b e 1959), combater a pressão inflacionária derivada das alterações na estrutura produtiva.

\section{Desenvolvimentismo, teoria da poupança forçada e o inflacionismo}

A relação da literatura desenvolvimentista com a teoria da poupança forçada é especialmente importante para este artigo. Franco (1996), ao definir o inflacionismo, sustenta que foi através do mecanismo da poupança forçada que os recursos gerados pela inflação e déficits públicos foram canalizados para o financiamento dos investimentos industriais. Um primeiro aspecto a salientar é que esta teoria não nasceu na América Latina, pois sua origem se encontra na literatura 
pós-keynesiana sobre crescimento econômico, especialmente após a elaboração da equação de Cambridge. Em sua forma mais simplificada, a equação informa que a taxa de acumulação de capital é uma função da propensão marginal a poupar e da taxa de lucro dos capitalistas. Marquetti; Koshiyama e Alencastro (2009) formalizam a equação de Cambridge da seguinte forma:

$$
g_{k}+d=s(r+d)
$$

Na qual, $g_{k}$ é a taxa de crescimento da acumulação de capital, $d$ a depreciação do capital, $s$ a taxa de poupança e $r$ a taxa de lucro.

A relação entre inflação, acumulação de capital e crescimento é bastante direta na literatura pós-keynesiana da década de 1950. Uma elevação dos preços, ao transferir renda dos trabalhadores para os capitalistas, contribuiria para elevar a poupança do sistema econômico (vale lembrar que a propensão marginal dos capitalistas é superior à dos trabalhadores, sendo muito comum nos modelos póskeynesianos da década de 50 assumir como hipótese simplificadora que os trabalhadores não poupam). Ao mesmo tempo, eleva a taxa de lucro, ou seja, amplia a acumulação de capital necessária para a realização dos investimentos, o que é o motor do crescimento econômico para esta literatura. Em última instância, a inflação ao transferir renda dos trabalhadores para os capitalistas, ampliaria, de modo forçado - e aí está a origem da denominação - a taxa de poupança do sistema.

O caminho pelo qual a difusão destas ideias chegou à América Latina extrapola o interesse e o alcance deste trabalho. Prebisch (1949) já faz referência ao debate. Em 1956, Nicholas Kaldor esteve no Brasil e proferiu a conferência "Inflation and Economic Development". Os debates realizados foram sintetizados em um artigo intitulado "Tributação e Desenvolvimento Econômico", publicado em 1957 pela Revista Brasileira de Economia. Neste artigo, Kaldor discute como a inflação e a tributação do consumo são fontes da poupança forçada. $\mathrm{O}$ autor, no entanto, defende que o mecanismo tributário é mais eficiente e socialmente mais justo do que a inflação para promover uma elevação do nível da poupança agregada e, consequentemente, da acumulação de capital.

Não existem evidências na obra de Simonsen, especialmente em seus debates econômicos com Gudin, do uso da "teoria da poupança forçada" como mecanismo de financiamento dos investimentos industriais. Vale lembrar que o industrialista faleceu em 1948. Simonsen, pelo contrário, preocupou-se em elaborar um modelo de financiamento dos investimentos industriais que não gerasse pressões inflacionárias sobre o sistema. Ao se questionar sobre a fonte de recursos, propõe ao governo "empenhar pelo menos $50 \%$ de suas atuais disponibilidades no estrangeiro" para viabilizar o financiamento dos investimentos industriais. Simonsen, como tantos outros e inclusive os técnicos do governo, certamente superestimou as "disponibilidades do país no estrangeiro". Essa discussão ficou conhecida na 
literatura como "ilusão de divisas", típica do período do imediato pós-guerra. O mais importante, no entanto, é que após a instalação da indústria “(...) intensificando a produção, concorreríamos para diminuir os efeitos das emissões já realizadas e para conter as atuais fontes inflacionistas" (Simonsen [1945], 2010, p. 46). Assim, a preocupação com a inflação levava o industrialista à conclusão que seria tradicional para o estruturalismo, isto é, que a industrialização ajudaria a reduzir a inflação.

A visão crítica de Campos em relação teoria da poupança forçada aparece de forma nítida em seus comentários sobre a visão que a $\mathrm{CNI}^{12}$ tinha do PEM, de 1958. Campos classifica como bizarra qualquer defesa da inflação como mecanismo de financiamento dos investimentos. Suas palavras sobre o tema não deixam dúvida sobre sua visão:

A oposição de grupos empresariais ao PEM, notadamente da CNI, assumiu aspectos bizarros. Alguns técnicos de linha estruturalista e nacionalista, ligados aos grupos industriais, passaram a defender a expansão inflacionária de crédito como um mecanismo permanente, e ainda válido no caso brasileiro, de transferência de recursos do consumo para investimentos. Era a velha tese da 'poupança forçada' a que o Professor Nicholas Kaldor, então em visita ao Brasil, havia dado novo glamour. Enquanto persistissem as condições de subdesenvolvimento, em que o fator escasso era o capital e não o trabalho, e dado o baixo poder de barganha dos assalariados, políticas expansionistas de crédito constituíam a principal opção para o aumento da taxa de investimento da economia. Esta tese contrariava frontalmente as premissas do PEM, de que a pressão salarial já se havia traduzido em inflação de custos, sendo necessário recorrer à política fiscal para o financiamento não inflacionário do Plano de Metas (Campos, 1994, p. 354).

Antes de apresentar as visões de Prebisch e Furtado sobre o tema, é necessário destacar que aqueles que discutiram a teoria da poupança forçada, especialmente a possibilidade de ampliar a acumulação de capital através da expansão da inflação, o fizeram destacando os limites deste processo. Via de regra, o viam como ineficiente e temporalmente limitado, em função de seus custos sociais. Retomando a opinião de Kaldor (1957, p. 84-85), acima citada, é interessante colocar suas palavras:

A criação de poupança pública através de excedentes orçamentários é, naturalmente, uma forma de "poupança forçada" análoga à de uma inflação. Mas há uma importante diferença. Como vimos, no caso da inflação, a poupança forçada se transforma numa redução obrigatória do consumo daqueles setores da comunidade - os recebedores de rendas contratuais, os salariados de um modo geral - cujos padrões de consumo são relativamente baixos e cuja capacidade real para "apertar o cinto" é, por conseguinte, pequena

(12) Confederação Nacional da Indústria. 
(...) A inflação nada faz para utilizar o verdadeiro potencial de poupança de um a comunidade através da compressão dos padrões de vida das classes mais abastadas, cuja capacidade para "apertar o cinto" é relativamente alta. Muito pelo contrário, uma vez que o aumento dos lucros (em termos reais e não apenas nominais) constitui um subproduto essencial do processo, tende a aumentar o consumo suntuário. $\mathrm{O}$ verdadeiro potencial de poupanças de uma comunidade consiste no seu "consumo desnecessário" - isto é, consumo em excesso sobre as necessidades mínimas, ou o que socialmente se considera um mínimo razoável - e que, por conseguinte, pode ser comprimido sem efeito desestimuladores da capacidade de trabalho e dos incentivos econômicos. Isto não pode ser alcançado através da inflação; entretanto, pode ser obtido (Kaldor, 1957, p. 84-85).

Prebisch (1949) discutiu a teoria da poupança forçada e sua aplicabilidade na América Latina. De acordo com o autor, "essa é uma tese digna de um exame cuidadoso. Dada a generalidade do processo, há uma profusão de fatos que oferecem um campo fértil de investigação, a partir da qual será possível avaliar seu valor e seu alcance" (Prebisch, 1949, p. 110). Após apresentar sua formulação básica ${ }^{13}$, o autor passa a estabelecer uma série de objeções e desqualificações à utilização da poupança forçada como mecanismo de financiamento aos investimentos industriais na América Latina, elementos que por vezes são negligenciados pela literatura, como por exemplo por Franco $(1996,2005)$.

A primeira objeção feita pelo autor é de natureza empírica, ao afirmar que não existiriam informações suficientes para defender este argumento nas experiências concretas de industrialização na América Latina. $\mathrm{O}$ autor afirma que "lamentavelmente não dispomos de elementos fidedignos que permitam que nos pronunciemos a esse respeito. As cifras isoladas não justificam nenhuma generalização" (Prebisch, 1949, p. 109). Prebisch também apresenta uma nítida desconfiança em relação à utilização dos recursos transferidos dos trabalhadores para os capitalistas ao argumentar que: "seria também de grande interesse indagar até que ponto essas possibilidades se traduziram numa poupança efetiva, e se a aplicação dessa poupança foi feita da forma mais produtiva para a coletividade" (Prebisch, 1949, p. 112). Em outros termos, o autor desconfia da hipótese, comum na literatura teórica, de que na América Latina a transferência de renda dos trabalhadores para os capitalistas de fato promoveria uma elevação na taxa de poupança, existia a possibilidade de que a mesma resultasse em uma elevação no consumo supérfluo dos capitalistas. Mais importante ainda, é destacar que o autor rechaça explicitamente o uso deste expediente, tendo em vista "as graves consequências da inflação" e a

(13) “A alta de preços, ao gerar lucros extraordinários, coloca nas mãos de um grupo relativamente pequeno grandes possibilidades de poupança, como sempre ocorre quando é assim alterada a distribuição da renda. (Prebisch, 1949, p. 112). 
existência de meios alternativos mais eficientes para ampliar o esforço de poupança sob controle do Estado.

Há ainda um outro aspecto a esclarecer. Supondo-se que, em determinadas circunstâncias, uma certa expansão inflacionária fosse considerada como o melhor expediente prático, dada a escassez de poupança, existiriam meios de promover um melhor cumprimento desse objetivo, atenuando, ao mesmo tempo, as graves consequências da inflação. O Estado tem em seu poder recursos que lhe permitem estimular a inversão de grande parte dos lucros e da renda inflacionários através do gravame progressivo daquilo que é gasto e consumido, ao mesmo tempo que se libera ou isenta aquilo que é investido, e também mediante o desvio, através do controle cambial ou dos impostos, daquilo que tende a ser empregado em importações incompatíveis com um ritmo intenso de crescimento econômico (Prebisch, 1949, p. 112. Grifo dos autores).

Prebisch ([1961], 1982) reconhece, tal como Furtado, que a inflação cumpriu um papel relevante no financiamento dos investimentos. No artigo intitulado " $E l$ falso dilema entre desarrollo económico y estabilidad monetária”, o autor já dispõe, ao contrário de seu artigo de 1949, de informações empíricas suficientes para diagnosticar, no contexto específico do subdesenvolvimento latino-americano, a importância da transferência de renda gerada pelo mecanismo de poupança forçada inflacionária. Não obstante, permanece no autor uma versão claramente crítica em relação ao uso deste expediente como mecanismo de financiamento. $\mathrm{O}$ autor afirma que é necessário "manter o volume de inversões antes realizadas inflacionariamente, cobrindo-as, porém, com poupança proveniente de impostos e da contribuição de recursos internacionais" (Prebisch, [1961], 1982, p. 21). O diagnóstico de Prebisch neste momento é, portanto, muito próximo da proposta apresentada por Kaldor em seus seminários de 1956, ao menos no que tange à necessidade de utilizar o instrumento fiscal como mecanismo de ampliação da poupança doméstica.

Furtado (1959), tal como Prebisch (1949), admite que a análise da elevação dos preços no financiamento dos investimentos no imediato pós-guerra "é um ponto de grande interesse, que vale a pena analisar". A discussão, no entanto, precisa ser bem qualificada. A primeira observação é que, tal como discutido na seção anterior, o autor tinha consciência dos efeitos danosos da inflação. Vale lembrar que a alta dos preços dos produtos industriais que contribuiu, ainda que em parte, para acumulação de capital na indústria, se fez às custas de uma redução na participação do restante da sociedade na renda real, já que "a inflação é fundamentalmente uma luta entre grupos pela redistribuição da renda real" (Furtado [1959], 1968, p. 239).

De fato, o autor reconhece a "funcionalidade" da inflação durante um período específico do processo de industrialização. Isto é muito claro em Furtado (1961, p. 255): 
O papel da inflação consistiu em abrir caminho contra as resistências organizadas ideologicamente predominantes. Assim, a elevação da rentabilidade relativa do setor industrial, nos anos trinta, levou muita gente a crer na indústria nacional, porque nela pôde ganhar tanto ou mais dinheiro quanto no velho setor exportador. No primeiro decênio do após-guerra, a inflação foi o instrumento que canalizou para as indústrias o fruto da melhora abrupta na relação de preços do intercâmbio. Na segunda metade dos cinquenta, a inflação decorreu da aceleração dos investimentos nos setores básicos, aceleração essa que era mais importante nessa etapa que outro qualquer objetivo econômico. Teria sido possível alcançar esses objetivos sem inflação? Provavelmente não, pois ainda não se havia formado no país uma clara consciência da natureza do problema do seu desenvolvimento (Furtado, 1961, p. 255).

A passagem acima, se analisada de forma isolada, pode, em alguma medida, subsidiar a visão que Furtado era um defensor do inflacionismo. Mas essa observação não pode ser feita a despeito de outra questão: qual o significado, para um economista preocupado com a construção de uma sociedade socialmente mais justa, em defender a inflação como mecanismo de financiamento dos investimentos industriais ${ }^{14}$

Para responder a indagação, em nossa opinião, é necessário retomar alguns elementos da obra de Furtado. $\mathrm{O}$ autor, em consonância com boa parte do pensamento cepalino dos anos 50 e da primeira metade da década de 60, entendia que o histórico subdesenvolvimento latino-americano era fruto do frágil desenvolvimento industrial. A industrialização era a forma de superar o subdesenvolvimento e todos os problemas dele decorrentes, no qual se inclui a própria inflação estrutural. Realizada a implantação da indústria no Brasil, as causas estruturais da inflação seriam removidas e, a partir disso, o país se comportaria tal como o centro desenvolvido, ou seja, com taxas de inflação inferiores a um dígito. Em outras palavras, não há em Furtado uma defesa teórica do mecanismo de financiamento via inflação ad infinitum. O que há é a constatação que no processo histórico de industrialização de uma economia subdesenvolvida, tal como a brasileira - em que não existia uma consciência das elites da necessidade de promover a industrialização e tampouco um sistema de financiamento de longo prazo -, a inflação desempenhou, por um período transitório, o da instalação da indústria pesada, um papel relevante na transferência de renda do setor agroexportador para o setor industrial, permitindo a acumulação de capital e o financiamento dos investimentos industriais.

A discussão promovida acima evidencia que Furtado desloca a discussão da poupança forçada de sua visão tradicional - conflito distributivo entre trabalhadores

(14) Cardoso (2013) ressalta a preocupação com justiça social de Furtado. 
e capitalistas - para a distribuição intersetorial da renda, isto é, entre industriais e agroexportadores. Este deslocamento é observado pela literatura especializada. Por exemplo, Boianovsky (2012, p. 306) argumenta que: “Whereas the conventional treatment of forced saving was framed in terms of the distribution of income between profits and wages, Furtado (1954, 174-87; [1959], chap. 35, [1960]1967; 1964) discussed how in an open economy... inflation favored on group of entrepreneurs (importers of capital goods) at the expense of another (exporters of primary goods).

É interessante incorporar ao debate as considerações posteriormente feitas por Furtado sobre a sua produção intelectual das décadas de 50 e 60. Em seu livro "Fantasia Organizada", publicado em 1985, Furtado promove uma revisão, de caráter autobiográfico, sobre o debate desenvolvimentista do período. Nestas reflexões, o autor deixa nítido o seu distanciamento com a "teoria da poupança forçada".

Estudando o período 1948-1952, chamara atenção para o fato de que a inflação fora fator causante da elevação da taxa de investimento. Não se tratava de voltar à velha discussão sobre se a taxa de inflação era ou não uma maneira de forçar o aumento de poupança, o que encobria seu aspecto altamente antisocial de instrumento compressor do consumo da massa da população. Eu pusera o acento em outra coisa: a inflação não gerava recursos, apenas modificava o perfil da apropriação dos novos recursos gerados pela melhora na relação de trocas (Furtado, 1985, p. 179).

Em última instância, de acordo com Furtado (1961), a causa essencial da inflação encontrava-se na ausência de um conjunto de políticas de desenvolvimento que permitissem ao mesmo tempo promover a industrialização e assegurar a estabilidade, reduzindo assim o custo social do processo de industrialização.

Em suma, o argumento de Franco $(1999,2004)$ de que Prebisch e Furtado são exemplos de defensores da teoria da poupança forçada e, portanto, do financiamento inflacionário dos investimentos industriais, desconsidera uma série de elementos fundamentais postos pelos autores. No caso específico de Furtado, o que há é a constatação que, dadas as condições históricas concretas do país, especialmente com o parco desenvolvimento do sistema financeiro nacional, a inflação serviu como mecanismo de transferência de renda entre setores (do agroexportador para o industrial). Isso permitiu a acumulação de capital na indústria, elemento necessário para a realização dos investimentos industriais. Instalada a indústria, cessariam as pressões estruturais sobre a inflação do país, sem incorrer nos custos de políticas econômicas restritivas.

\section{Considerações finais}

Sob diversos os ângulos possíveis, o projeto desenvolvimentista constituiuse em uma verdadeira heresia para os cânones da teoria econômica padrão. Não é 
difícil entender por que o projeto desenvolvimentista foi criticado pelos líderes do pensamento liberal e por que é sumariamente desqualificado por autores contemporâneos como Franco.

A rigor, generalizações sobre o tema da inflação nos expoentes desenvolvimentistas levam a conclusões imprecisas, quando não equivocadas. A construção de um projeto de superação do subdesenvolvimento através da industrialização integral, por meio do planejamento e da intervenção direta do Estado na atividade econômica era o elo de união das diversas correntes desenvolvimentistas. Nos demais campos, tal como no estudo da inflação, reinava a heterogeneidade nas interpretações. Não obstante, os argumentos apresentados ao longo do artigo, permitem concluir que:

1) Não existem elementos que respaldem a visão da leniência inflacionária. A inflação era vista pelos líderes intelectuais das correntes desenvolvimentistas, especificamente Simonsen, Furtado e Campos, como um problema a ser enfrentado. Adicionalmente, é necessário sublinhar o reconhecimento dos problemas gerados pela inflação para o desenvolvimento, especialmente seus efeitos regressivos sobre a distribuição da renda. Afirmar que o desenvolvimentismo tinha "uma certa complacência" com a inflação é algo muito impreciso, uma estilização. Mais preciso é afirmar que, em parte da literatura desenvolvimentista, a inflação não se constituiu no objetivo central (ou exclusivo) da política econômica. $\mathrm{Na}$ hierarquia de prioridades de autores como Simonsen e Furtado, a inflação ocupava posto inferior à promoção do crescimento e aos avanços no processo de industrialização. $\mathrm{O}$ mesmo não pode ser dito sobre Campos, mesmo em sua fase desenvolvimentista.

A tese da leniência inflacionária não encontra respaldo também nas análises das evidências empíricas promovidas pelas pesquisas recentes na área de história econômica. Ainda que não seja o foco deste trabalho, cuja ênfase se encontra na discussão da história do pensamento, vale a pena destacar, tal como anunciado na introdução deste trabalho, que Mollo e Fonseca (2013) concluem que não existem evidências da tese de "leniência inflacionária" nas duas gestões de Vargas (19301945 e 1951-1954) ${ }^{15}$. Não pode-se dizer também que a gestão Dutra tenha sido leniente ou complacente com a inflação, já que o controle de preços foi eleito como o principal problema econômico a ser enfrentado pela política econômica. A gestão de JK foi marcada pela implantação do Plano de Metas. A magnitude e a concentração dos esforços do governo para cumprir as metas do Plano justificam a

(15) Para uma análise detalhada da política econômica de Vargas recomenda-se a leitura de Bastos (2008) e Fonseca (2011). O primeiro promove uma minuciosa análise da política econômica de Vargas durante os anos 1930. O segundo concentra suas discussões na análise do governo Vargas entre 1951-1954. A ideia de que Vargas era complacente com a inflação não se sustenta na análise dos fatos históricos, como se depreende da leitura de Bastos (2008) e Fonseca (2011). 
sua centralidade nas análises econômicas sobre a gestão JK. É importante lembrar, no entanto, que em 1958 foi lançado o Plano de Estabilização Monetária, (PEM) elaborado por Lucas Lopes, com participação de Roberto Campos, então presidente do BNDE. Não restam dúvidas que entre os efeitos concretos do Plano de Metas e a proposta de combate à inflação do PEM, JK deu clara preferência ao primeiro. Roberto Campos, em suas memórias, relata que a opção pelo Plano de Metas e a quase recusa em colocar em prática as medidas anti-inflacionárias do PEM foi uma decisão de $\mathrm{JK}$, e não da equipe técnica. O episódio deixa claro que não há uma correlação perfeita entre as ações concretas dos governos no âmbito da condução da política econômica e as discussões promovidas pelos intelectuais em seus debates acadêmicos. Finalmente, outra lição da discussão é que a negligência no trato com a questão inflacionária ocorreu, para o período analisado, exclusivamente no governo JK, não podendo ser generalizada para outros períodos, como pretende a interpretação inflacionista proposta por Franco $(1996,2005)$.

2) Os líderes intelectuais do desenvolvimentismo não defendiam a utilização da inflação como mecanismo para financiamento dos investimentos industriais, tal como discutido na seção 3 do trabalho. Tal como na discussão sobre as causas da inflação, a análise da relação entre inflação e a teoria da poupança forçada é marcada pela heterogeneidade. Simonsen ignora a teoria, enquanto Campos critica-a de forma veemente. Prebisch, apesar de reconhecer o interesse sobre a matéria, nega a sua viabilidade. Furtado reconhece a funcionalidade da alta de preços em um processo temporário de transferência de recursos, nota também que a inflação, no contexto histórico específico de uma economia subdesenvolvida do pós-guerra, ajudou na acumulação de capital, mas em nenhum momento propõe a utilização da inflação como mecanismo de financiamento de longo prazo dos investimentos.

Não é possível, no entanto, afirmar que em todos os espaços da discussão desenvolvimentista a teoria da poupança forçada tenha sido criticada e/ou vista com severas restrições. Saretta (2008) apresenta evidências de que a defesa explícita da teoria foi realizada por um grupo de economistas da CNI, especialmente em suas críticas ao PEM, de 1958. Feita esta ressalva, a conclusão final é que não existem evidências suficientes para sustentar que os expoentes do desenvolvimentismo brasileiro eram defensores de um mecanismo de financiamento inflacionário dos investimentos industriais.

A recuperação da visão dos expoentes desenvolvimentistas do período sobre o tema da inflação realizada neste artigo pretende, portanto, contribuir para este debate, especialmente para um tratamento mais cuidadoso da literatura econômica. Um cuidado especial deve ser tomado na separação entre o que era proposto pela literatura econômica desenvolvimentista e as ações concretas da política econômica do período em que esta literatura foi influente. A tese inflacionista desqualifica a literatura desenvolvimentista, obscurecendo seu significado e consolidando, nas 
novas gerações de jovens economistas, uma visão equivocada sobre autores que contribuíram de forma fundamental na construção do pensamento econômico brasileiro.

\section{Referências bibliográficas}

ABREU, M. P. O Brasil e a economia mundial, 1930-1945. Rio de Janeiro: Civilização Brasileira, 1999.

BAER, W. The inflation controversy in Latin America: a survey. Latin American Research Review, n. 2, 1967.

BARBOSA, F. H. A inflação brasileira no após-guerra: monetarismo $\mathrm{x}$ estruturalismo. Rio de Janeiro: Ipea/Inpes, 1983. (Série PNPE, n. 8).

BASTOS, P. P. Z. Ortodoxia e heterodoxia antes e durante a Era Vargas: contribuições para uma economia política da gestão macroeconômica dos anos 1930 . Economia, Anpec (Selecta), v. 9, n. 4, dez. 2008.

BIELSCHOWSKY, R. Pensamento econômico brasileiro: o ciclo ideológico do desenvolvimentismo. Rio de Janeiro: Ipea/Inpes, 1988. (Série PNPE, n. 19).

BOIANOVSKY, M. Celso Furtado and the structuralist-monetarist debate on economic stabilization in Latin America. History of Political Economy, v. 44, n. 2, p. 277-330, 2012.

BRESSER-PEREIRA, L. C. O novo desenvolvimentismo e a ortodoxia convencional. São Paulo em Perspectiva, v 20, n. 3, p. 5-24, 2006.

Globalization and competition: why some emergent countries succeed while others fall behind. Cambridge University Press, 2010.

CAMPOS, R. A crise econômica brasileira. Digesto Econômico, São Paulo, nov. 1953.

. Economia, planejamento e nacionalismo. Rio de Janeiro: APEC, 1963.

. Reflection on Latin American development. Austin: Texas University

Press, 1967.

A lanterna na popa: memórias. 2. ed. Rio de Janeiro: Top Books, 1994.

CARDOSO, F. H. Pensadores que inventaram o Brasil. São Paulo: Companhia da Letras, 2013.

CARONE, E. Roberto C Simonsen e sua Obra. Revista de Administração de Empresas, Rio de Janeiro, v. 11, n. 4, p. 23-28, out./dez. 1971. 
COELHO, F. S.; GRANZIERA, R. G. Celso Furtado e a formação econômica do Brasil. Edição Comemorativa dos 50 anos de publicação (1959-2009). São Paulo: Ordem dos Economistas do Brasil (OEB) e Atlas, 2009.

CRAVEN, C. A transformation problem: monetarismo to structuralism in the Economic Commission for Latin America. History of Political Economy, v. 26, n. 1, 1994.

CURI, L. F. B.; CUNHA, A. M. Redimensionando a contribuição de Roberto Simonsen à controvérsia do planejamento (1944-45): pioneirismo e sintonia. In: ENCONTRO DA ASSOCIAÇÃO NACIONAL DE PÓS-GRADUAÇÃO EM ECONOMIA, 39. Foz do Iguaçu, PR: Anpec, 2011.

; SAES, A. M. Roberto Simonsen e Wladimir Woytinsky no período entreguerras: um ambiente de questionamento à ortodoxia. In: ENCONTRO DA ASSOCIAÇÃO NACIONAL DE PÓS-GRADUAÇÃO EM ECONOMIA, 40. Porto de Galinhas, PE: Anpec, 2012.

DOELLINGER, C. V. Introdução. [1977]. In: SIMONSEN, R. C.; GUDIN, E. A controvérsia do planejamento na economia brasileira. 3. ed. Brasília: Ipea, 2010.

FONSECA, P. C. D. As origens e as vertentes formadoras do pensamento cepalino. Revista Brasileira de Economia, Rio de Janeiro, v. 54, n. 3, jul./set. 2000.

. Gênese e precursores do desenvolvimentismo no Brasil. Pesquisa \& Debate, v. 15, n. 2 (26), 2004.

- O mito do populismo econômico de Vargas. Revista de Economia Política, São Paulo, v. 31, n. 1 (121), jan./mar. 2011.

FRANCO, G. H. B. O desafio brasileiro: ensaios sobre desenvolvimento, globalização e moeda. Editora 34, 1996.

Auge e declínio do inflacionismo no Brasil. In: GIAMBIAGI, G; VILlELA, A.; CASTRO, L. B.; HERMANN, J. (Org.). Economia brasileira contemporânea (1945-2004). Rio de Janeiro: Campus Elsevier, 2005.

FURTADO, C. Características gerais da economia brasileira. Revista Brasileira de Economia, v. 4, p. 7-37, 1950.

. Formação de capital e desenvolvimento econômico. Revista Brasileira de Economia, v. 6, n. 3, p. 7-45, 1952.

The external disequilibrium in the underdeveloped economies. Indian Journal of Economics, v. 38, p. 403-410, 1958a.

Perspectivas da economia brasileira. Rio de Janeiro: ISEB, $1958 \mathrm{~b}$. 
FURTADO, C. Formação econômica do Brasil. Rio de Janeiro: Companhia Editora Nacional, [1959] 1968.

. Desenvolvimento e subdesenvolvimento. Rio de Janeiro: Fundo de Cultura, 1961.

A fantasia organizada. Rio de Janeiro: Paz e Terra, 1985.

GODOY, B. B. C. A influência de Roberto Campos na economia brasileira (19452001). Dissertação (Mestrado)-Programa de Pós-Graduação em História Econômica da Universidade de São Paulo (USP), 2007

KALDOR, N. Tributação e desenvolvimento econômico. Revista Brasileira de Economia, 1957.

KAY, C. Reflections on the Latin American Contribution to Development Theory. Development and Change, v. 22, p. 31-68, 1991.

MANTEGA, G. Economia política brasileira. São Paulo; Petrópolis: Vozes, 1984.

MARQUETTI, A.; KOSHIYAMA, D.; ALENCASTRO, D. O aumento da lucratividade expande a acumulação de capital? uma análise de causalidade de Granger para países da OCDE. Revista de Economia Contemporânea, Rio de Janeiro, v.13. n. 3, 2009.

MAZA, F. O idealismo prático de Roberto Simonsen: ciência, tecnologia e indústria na formação da Nação. Tese (Doutorado)-Programa de Pós-Graduação em História Social. Universidade de São Paulo, 2002.

MELLO, J. M. C. O capitalismo tardio. São Paulo: Editora Brasiliense, 1982.

MOLLO, M. R. L.; FONSECA, P. C. D. Desenvolvimentismo e novodesenvolvimentismo: raízes teóricas e precisões conceituais. Revista de Economia Política, v. 33, n. 2 (131), p. 222-239, abr./jun. 2013.

NOYOLA, J. El desarrollo economico y la inflacion en Mexico y otros paises latinoamericanos. Investigacion Economica, v. 16, n. 4, p. 602-648, 1956.

PREBISCH, R. The economic development of Latin America and its principal problems. Economic Commission for Latin America, 1949. (Document ECN 12.89).

. El falso dilema entre desarrollo económico y estabilidad monetaria. In:

GURRIERI, A. La obra de Prebisch en la Cepal. México: Fondo de Cultura Económica, [1961], 1982.

SARETTA, F. A Confederação Nacional da Indústria e o Plano de Estabilização Monetária de 1958. In: ENCONTRO DA ASSOCIAÇÃO NACIONAL DE ECONOMIA, 36. Salvador (BA): Anpec, 2008.

SIMONSEN, R. As crises no Brasil. São Paulo: São Paulo Editora Limitada, 1930. 
SIMONSEN, R. As finanças e a indústria. São Paulo: São Paulo Editora Limitada, 1931. . Elos da indústria. São Paulo: Fiesp, 1944.

. A planificação da economia brasileira. In: SIMONSEN, R.; GUDIN, E.; VON DOELLINGER, C. A controvérsia do planejamento na economia brasileira. 3. ed. Brasília: Ipea, 2010a.

- O planejamento da economia brasileira - Réplica ao Sr. Eugênio Gudin. In: SIMONSEN, R.; GUDIN, E.; VON DOELLINGER, C. A controvérsia do planejamento na economia brasileira. 3. ed. Brasília: Ipea, $2010 \mathrm{~b}$.

SEERS, D. A theory of inflation and growth in underdeveloped economies based on the experience of Latin America. Oxford Economic Papers, v. 14, n. 2, p. 173 $195,1962$.

SUNKEL. O. Inflation in Chile: an unorthodox approach. International Economic Papers, 10, p. 107-117, 1960.

SZMRECSÁNYI, T. Pensamento econômico no Brasil contemporâneo: Celso Furtado. Estudos Avançados, São Paulo, v.15, n. 43, Sept./Dec. 2001.

TEIXEIRA, A.; MARINGONI, G.; GENTIL, L. Roberto Simonsen e Eugênio Gudin: desenvolvimento, o debate pioneiro (1944-45). Brasília: Instituto de Pesquisa Econômica Aplicada, 2010. 